\title{
The Huguenots and the imaginative geography of Ireland: a planned immigration scheme in the 1680 s
}

$\mathrm{T}$ he phenomenon of European migration during the early modern period whether to overseas locations or across frontiers within Europe - is a complex one. ${ }^{1}$ In general, people migrate of their own volition from places of low opportunity or deprivation to areas of higher opportunity, where they hope to find employment or a better life. ${ }^{2}$ In the early modern period, however, the reasons why people migrated are less clear. Of course, many thousands migrated to improve their circumstances, usually in the hope of returning to make a permanent home in their place of origin. Yet, according to Nicholas Canny, English migration to transatlantic destinations in the early part of the seventeenth century was 'high-risk subsistence migration', since both the Chesapeake and the West Indies proved lethal for Europeans. The precise reasons why migrants continued to leave home, when such were the prospects before them, remain opaque to historians. ${ }^{3}$

However, the experience of the early modern period suggests that migration occurred, especially to overseas destinations, where certain networks were already in place. Transport was one of the most important. Migrants tended to move to those overseas locations which merchants found it profitable to promote or to which passage was paid in advance. Information networks were also crucial. People were more inclined to migrate when they had effective feedback about destinations, particularly personal information from friends and family. In addition, they moved when they were actively recruited by promoting agents for immigration schemes that had been planned in advance to places where locators would assist them to settle. Therefore, in order to understand the phenomenon of Europeans on the move in the early modern period, it is necessary to uncover their networks of transport, information, propaganda and recruitment. ${ }^{4}$

I Nicholas Canny, 'In search of a better home? European overseas migration, $1500-1800^{\prime}$ in idem (ed.), Europeans on the move: studies on European migration, 1500-1800 (Oxford, 1994), p. 267.

2 P. J. Duffy, 'Migration management in Ireland' in idem (ed.), To and from Ireland: planned migration schemes, c. 1600-2000 (Dublin, 2004), p. 3.

${ }^{3}$ Canny, 'In search of a better home?', pp 266, 273, 277; idem, 'English migration into and across the Atlantic during the seventeenth and eighteen centuries', ibid., p. 75.

${ }^{4}$ Canny, 'In search of a better home?', p. 278; Duffy, 'Migration management', p. 12; Bernard Bailyn, 'Europeans on the move, 1500-1800' in Canny (ed.), Europeans on the move, p. 5; David Cressy, Coming over: migration and communication between England and New England in the seventeenth century (Cambridge, 1987), pp 74-106, 213-34. 
At first glance, such considerations have little to do with the emigration of some 150,000 to 250,000 Huguenots to Switzerland, England and the Dutch Republic, whence secondary migrations carried them to the RhinelandPalatinate, Ireland, Scandinavia, British North America and South Africa. ${ }^{5}$ Of course, French Protestants left home in search of a better life, which they framed in terms of freedom from religious persecution. But the 'push factor' was paramount in that exceptional mass movement of population. As one eighteenthcentury commentator observed, only 'quelque grand sujet qui ser[t] de machine' could have motivated them to turn their backs on 'l'amour de la patrie, les possessions, les établissemens, les parens, et les amis, le bon air, l'abondance du vin, et les autres commoditez de la vie'. 6 The Huguenots were - so to speak accidental emigrants, people for whom the word 'refugee' was imported into the English language in the $1680 \mathrm{~s}$ to express the desperation that made people flee from home to a strange place where they hoped to find asylum from oppression. That is not the whole story, however.

Unquestionably, the pattern of emigration in the 1680s reveals that Huguenots fled to destinations that were familiar, easier to reach, and deemed safe because Protestant. Not only were there strong trading links between France and the three main centres of refuge - Switzerland, England and the Dutch Republic - but those countries had also been welcoming French refugees from the sixteenth century, and all had French churches. Furthermore, while the Huguenot emigration was exceptional because of the numbers leaving and the reasons why they did so, their aspirations were no different from those of other peoples who chose to migrate in the early modern period. The population of Bourbon France was not sedentary and immobile; rather the contrary. Geographical mobility and seasonal migration were normal, with people moving often over long distances to earn income to maintain their households. All, even those who migrated overseas, had little intention of settling there for life, retaining instead the hope of returning home, as did the Huguenots. ${ }^{7}$ This continued to be their dream until the terms of the treaty of Ryswick (1697) and later the treaties of Utrecht (1713-15) made it clear that there would be no restoration of the Protestants to France. ${ }^{8}$ But when they fled in their thousands in the 1680 s, the Huguenots were still clinging to the hope that their exile would be short-lived, and that staying near France left all options open.

\footnotetext{
${ }^{5}$ Peter Moogk, 'Manon's fellow exiles: emigration from France to North America before 1763 ' in Canny (ed.), Europeans on the move, p. 242, which suggests that the settlement in the Rhineland-Palatinate was a primary migration. Although many Huguenots emigrated to the Rhineland-Palatinate in 1681, the majority settled there in secondary migrations from the United Provinces and Switzerland after the revocation of the Edict of Nantes in 1685, largely in response to recruitment initiatives.

6 'some major cause which acted as a propulsion'; 'the love for homeland, belongings, households, kin and kith, the fine air, plentiful wine, and other of life's conveniences'. The comment is made by the editor of the early eighteenth-century edition of Jean Claude, Les plaintes des Protestans, cruellement oprimez dans le royaume de France (London, 1707), p. 10, which was originally published in 1686 .

${ }^{7}$ Moogk, 'Manon's fellow exiles', p. 243; Élisabeth Labrousse, 'Le refuge huguenot' in Le Genre Humain, xix (1989), p. 153.

${ }^{8} \mathrm{~L}$. H. Boles, The Huguenots, the Protestant interest, and the War of the Spanish Succession (New York, 1997), pp 195-257.
} 
The mass movement of Protestants from France began in March 1681, and escalated in May when Marillac, the intendant of Poitou, billeted dragoons on Huguenot households as a means of exerting pressure on them to convert to Roman Catholicism. The results were spectacular: 30,000 abjurations were recorded in the space of a few weeks, while thousands fled to the traditional centres of refuge, despite the penalties meted out to those who were caught fleeing the country. ${ }^{9}$ They brought with them stories of the brutalities either witnessed or experienced, which galvanised Protestant Europe into action. In the early summer Frederick William, Elector of Brandenburg-Prussia, expressed his displeasure to Count Rébenac, the French envoy at his court. ${ }^{10}$ At the end of July Charles II of England offered the Huguenots a home and significant privileges, and encouraged charitable support for them once they had arrived. ${ }^{11}$ In August Christian II made an official offer of asylum and charitable aid to French Protestants taking refuge in Denmark. ${ }^{12}$ In the autumn Amsterdam, Groningen, the States of Holland and the province of Friesland offered tax exemptions and other incentives to refugees settling in the United Provinces. ${ }^{13}$ In Ireland the viceroy, James Butler, first duke of Ormond, proposed on 11 November that members of the privy council make a charitable donation for the relief of the French refugees arriving in Ireland, and a motion was passed authorising the city assembly of Dublin to make a house-to-house collection. The assembly also ordered that French refugees be admitted for a period of five years to the freedom of the city without fines or fees, and that they be exempt from city taxes - but this applied only to those who were "artizants and handicraftsmen' ${ }^{14}$ It is generally assumed that this combination of factors, both 'push' (dragonnades) and 'pull' (incentives), encouraged individual Huguenots to migrate to Ireland

${ }^{9}$ Élisabeth Labrousse, 'Une foi, une loi, un roi'? La révocation de l'Édit de Nantes (Paris, 1985), pp 173-34.

${ }^{10}$ Ibid., p. 175.

${ }^{11}$ Cal. S.P. dom., 1680-81, pp 366, 397-8, 525, 561, 622, 629; R. D. Gwynn, 'Government policy towards Huguenot immigration and settlement in England and Ireland' in C. E. J. Caldicott, Hugh Gough and Jean-Paul Pittion (eds), The Huguenots and Ireland: anatomy of an emigration (Dublin, 1987), pp 215-17; idem, Huguenot heritage: the history and contribution of the Huguenots in Britain (2nd ed., Brighton, 2001), pp 166-7.

${ }_{12}$ Labrousse, 'Une foi, une loi, un roi'?, p. 175.

${ }^{13}$ News of this reached England in October: Cal. S.P. dom., 1680-81, p. 511; H. P. H. Nusteling, 'The Netherlands and the Huguenot émigrés' in J, A. H. Bots and G. H. M. Posthumus Meyjes (eds), La révocation de l'Édit de Nantes et les Provinces-Unies (Amsterdam \& Maarssen, 1986), pp 17-19.

${ }^{14}$ Anc. rec. Dublin, v, 228-9; [Pierre Drelincourt], De l'état present d'Irlande, et des avantages qu'y peuvent trouver les protestans françois: en une lettre d'un des chapelains de monseigneur le duc d'Ormond, viceroi d'Irlande, à un de ses amis en Angleterre (Dublin, 1681), pp 6-7, which was reliably attributed to Drelincourt by the late Mary Pollard. The text of this pamphlet is published in Ruth Whelan, 'Representing Ireland through imperial eyes: a Huguenot recruitment document in 1681' in Michael Brophy, Phyllis Gaffney and Mary Gallagher (eds), Reverberations: staging relations in French 
and elsewhere in the early $1680 \mathrm{~s}^{15}$ New evidence suggests a more complex picture for Ireland, however.

In reality, the hundreds of French Protestants who arrived in Dublin between 1681 and 1684 probably came in response to more extensive measures taken to recruit them, which were initiated by the duke of Ormond. Although recruitment literature is very rare, three immigration prospectuses have come to light: two manuscripts (possibly versions of a single text) and one published pamphlet, all composed on Ormond's instructions. Pierre Drelincourt (1644-1722) is undoubtedly the author of the pamphlet, dated 15 December 1681 and published in Dublin. ${ }^{16}$ It is not clear how Drelincourt came to Ormond's attention, but it was probably through family connexions. Pierre's father, Charles, was a distinguished pastor at the French Reformed temple at Charenton outside Paris, where Ormond occasionally attended services with the future Charles II during his years of continental exile. Pierre studied theology at Geneva (1666), Oxford (1671) and later Leiden (1675), where his brother Charles held the chair of anatomy. In 1678 he became private tutor to Lord James Butler, Ormond's grandson, teaching him French, history, geography and religion, and exercising moral and financial oversight on his charge, who remained in Oxford until 1680. In 1681 Ormond appointed Drelincourt his 'domestick chaplain', possibly with a view to using him to recruit Huguenots and to provide pastoral and practical care when they arrived. ${ }^{17}$ This is certainly the role Drelincourt was playing once the refugees landed in Dublin on 9 November $1681 . .^{18}$ Although the manuscripts - one in a copperplate hand, the other in an almost illegible notarial script - are anonymous and undated, ${ }^{19}$ internal evidence suggests that they were copied from an original that may also have been written by Drelincourt earlier in the same

since 1500: a festschrift in honour of C. E. J. Caldicott (forthcoming, Dublin, 2007). See also R. P. Hylton, 'The Huguenot communities in Dublin, 1662-1745' (Ph.D. thesis, University College Dublin, 1985), p. 40; idem, Ireland's Huguenots and their refuge, 1662-1745: an unlikely haven (Brighton, 2005), pp 34-5, which seems unaware of the three immigration prospectuses analysed in the present article; Mary Clark, 'Foreigners and freedom: the Huguenot refuge in Dublin city, 1660-1700' in Proceedings of the Huguenot Society of Great Britain and Ireland (henceforth Huguenot Soc. Proc.), xxvii (2000), pp 385-6.

is Clark, 'Foreigners and freedom', p. 385; Gwynn, 'Government policy', pp 216-17; R. P. Hylton, 'Dublin's Huguenot refuge, 1662-1817' in Dublin Hist. Rec., xl (1986-7), p. 18; idem, Ireland's Huguenots \& their refuge, pp 34-5.

1. [Drelincourt], De l'état presente d'Irlande (see above, n. 14)

${ }^{17} \mathrm{Jane}$ McKee, 'Pierre Drelincourt et sa contribution à la vie intellectuelle en Angleterre et en Irlande' in Jens Häseler and Antony McKenna (eds), La vie intellectuelle aux refuges protestonts (Paris, 1999), pp 269-88; Oxford D.N.B.

${ }^{18}$ [Drelincourt], De l'état present d'Irlande, p. 6.

${ }^{19}$ 'Mémoire pour encourager les protestans de venir habiter en Hirlande' (Bibliothèque Nationale de France, Paris (henceforth B.N.), MS f.fr. 21622; MS f.fr. 304 (Coll. Clérambault)) includes 'Mémoire pour encourager les protestans de venir s'habituer [sic] en Irlande'. The text of the manuscripts is substantially the same, although there are a few significant variants, introduced by the copyists, either deliberately or through inattentiveness: see Ruth Whelan, 'Promised land: selling Ireland to French Protestants in
the 1680s' (forthcoming). 
year. I shall argue from circumstantial evidence that it is more likely that the manuscripts went into circulation in 1681, and not in 1684 as has been suggested elsewhere. ${ }^{20}$

The likelihood that the manuscript and printed immigration prospectuses were by the same person, namely Drelincourt, is confirmed by the recurrence of identical expressions in the description of Ireland's natural advantages and political establishment. Of course, another writer could have simply lifted those expressions from Drelincourt and copied them into the manuscript prospectus later. Alternatively, Drelincourt might have derived inspiration from the manuscript, which had been composed by an unknown author at some earlier date. However, all three texts are framed as a response to the persecution of French Protestants and refer to the fact that, in the face of it, they are obliged 'à fuir d'un lieu à l'autre, selon l'ordre de l'Evangile'. ${ }^{21}$ Although penal measures against the Huguenots were stepped up after 1679,22 it was the dragonnades from March 1681 that they thought of as the start of what they called the 'great persecution', which culminated in the revocation of the Edict of Nantes (18 October 1685). Drelincourt wrote his pamphlet at the end of 1681, making it clear that he is referring to the traumatic events of the previous summer, and it is probable that the copyists are doing likewise. Since Ormond is mentioned in both manuscripts as viceroy of Ireland, they cannot be referring to the revocation, which occurred after Ormond's removal from office in February $1685 .{ }^{23}$ There is, of course, a remote possibility that the manuscript memoirs date from an earlier period. While circumstantial evidence again makes that unlikely, it is worth dwelling on the reasons why that is so, if only to dismiss them.

Following the 'Act for encouraging protestant-strangers and others, to inhabit and plant in the kingdom of Ireland', passed in the autumn of 1662, Ormond sent agents to England, the Low Countries and France to attract skilled Protestant artisans to assist in the formation of new industries, particularly the linen and woollen trades. His initiatives met with some limited success. By the end of 1668 an estimated two hundred Huguenots had immigrated, and fourteen two-storey houses had been built at Chapelizod to accommodate craftspeople from Holland. ${ }^{24}$ In fact by 1665 the number of francophone immigrants in the city of Dublin was such as to prompt the House of Commons to launch a subscription for the conversion of the Lady Chapel of St Patrick's cathedral as a place of worship where a French translation of the Anglican liturgy might be 'constantly

${ }^{20}$ E. G. Fayçal, 'En marge du tricentenaire de la révocation: un mémoire inédit destiné à favoriser l'établissement des Protestants français en Irlande (1684)' in Annales de Bretagne et des Pays de l'Ouest, xcii (1985), pp 403-9.

21 'to flee from one place to another, as the Scripture commands' (B.N., MS f.fr. 21622 , f. 74; MS f.fr. 304, f. 358; [Drelincourt], De l'état present d'Irlande, p. 3) (the allusion is to Matthew 10:23). For the variants between the manuscript and printed texts see Whelan, 'Promised land'.

${ }^{22}$ Labrousse, 'Une foi, une loi, un roi'?, pp 167-95.

${ }^{23}$ Oxford D.N.B. entry on Ormond.

24 Bodl,, Carte MS 36, ff 330, 521, 609, quoted in Raymond Gillespie, 'Planned migration to Ireland in the seventeenth century' in Duffy (ed.), To \& from Ireland, pp 47-8; Hylton, 'Huguenot communities in Dublin', pp 17-22; idem, 'Dublin's Huguenot refuge', pp 15-16; idem, Ireland's Huguenots \& their refuge, pp 19-31. 
read'. ${ }^{25}$ The French church was solemnly inaugurated on Sunday 29 April 1666, and from its inception was to be 'governed wholly according to the discipline and rites of the Church of Ireland, and the canons of the same strictly and indispensably'. ${ }^{26}$ This stipulation actually limited the freedom of worship implicitly extended to foreign Protestants under the 1662 act, which required them to swear the oaths of supremacy and allegiance, but not that of uniformity. ${ }^{27}$ Yet Ormond anticipated that the French immigrants 'would cheerfully and with much advantage to their souls frequent those ordinances in a language better known to them' ${ }^{28} \mathrm{He}$ was wrong. In 1668 'Protestants of divers parts of Europe' who were contemplating settling in Ireland petitioned Charles II that they might 'enjoy free exercise of their religion according to the discipline under which they have been bred', ${ }^{29}$ but no additional arrangements were made to accommodate them. After 1670 the number of Huguenot immigrants declined sharply. Raymond Gillespie is inclined to attribute this to the trade depression of the mid1660 s, generated by the First Dutch War. ${ }^{30}$ Economic factors undoubtedly played an important part, as did Ormond's removal from the viceroyalty in 1669 , but the limitations imposed on their freedom of worship should not be underestimated. By 1672 the number of French immigrants in Dublin had dwindled to some seventy people, and did not begin to rise again until 1681, which brings us back to the recruitment documents. ${ }^{31}$

Ireland was one of Europe's lesser-known areas in the early modern period and figured little in contemporary French travelogues. ${ }^{32}$ Indeed, when Albert Jouvin de Rochefort came to Ireland in 1668, he reported that people 'seemed astonished that out of mere curiosity I should come to see Ireland ... a country so retired and almost unknown to foreign travellers' ${ }^{33}$ It was also an unlikely destination for Huguenots fleeing from a predominantly Catholic country, since exaggerated rumours about the massacres of Protestants in Ireland in 1641 had circulated widely. ${ }^{34}$ All three memorials set out to convince potential immigrants of the advantages offered by moving to Ireland, and to provide reassurance by anticipating and diffusing their fears. All, using precisely the same words, insist

${ }^{25}$ Commons' jn. Ire. (3rd ed.), i, 700; Ruth Whelan, 'Liberté de culte, liberté de conscience? Les Huguenots en Irlande, 1662-1702' in Häseler \& McKenna (eds), La vie intellectuelle, $\mathrm{pp}$ 71-2.

${ }^{26}$ Ormond to Abp Boyle, 30 Nov. 1665, quoted in T. P. LeFanu, 'The French church in the Lady Chapel of St Patrick's cathedral, 1666-1816' in H. J. Lawlor, The fasti of St Patrick's, Dublin (Dundalk, 1930), p. 278; Hylton, Ireland's Huguenots \& their refuge, p. 25. Thus the congregation at the Lady Chapel was not permitted to retain their Calvinist ecclesiastical polity, as Gillespie alleges ('Planned migration', p. 55).

${ }^{27}$ Gillespie, 'Planned migration', pp 50, 54.

${ }^{28}$ Ormond to Abp Boyle, 30 Nov. 1665, quoted in Lawlor, Fasti, p. 278.

${ }^{29}$ Bodl., Carte MS 45, f. 578, quoted in Gillespie, 'Planned migration', p. 54.

${ }^{30}$ Gillespie, 'Planned migration', p. 55.

${ }^{31}$ Hylton, 'Huguenot communities in Dublin', p. 26; idem, 'Dublin's Huguenot refuge', p. 17; idem, Ireland's Huguenots \& their refuge, pp 29-30.

32 Jane Conroy, 'Changing perspectives: French travelers in Ireland, 1785-1835' in eadem (ed.), Cross-cultural travel: papers from the Royal Irish Academy symposium on literature and travel (New York, 2003), pp xx, 132.

${ }^{33}$ Andrew Browning (ed.), English historical documents, viii: 1660-1714 (London, 1953), p. 722.

${ }^{34}$ Gwynn, 'Government policy', p. 214. 
that immigrants may expect to live 'en une si grande liberté pour le temporel et pour le spirituel' under 'le gouvernement si excellant' and 'des loix si douces' of a country where 'ils doivent s'assurer d'estre favorablement receus, et s'y peuvent aisement establir'. ${ }^{35}$ This overly idealised, and even partisan, representation of the laws and government of early modern Ireland takes the threat out of the unknown, but it does so by airbrushing the Catholic populace out of the picture. The future of the immigrants was also to be guaranteed by the patronage of the duke of Ormond, his zeal for Protestantism and his commitment to the welfare of the refugees, which all sources 'prove' by pointing to the French church in Dublin. This means that the manuscript could not have been written before April 1666, when the French episcopalian church was ceremonially opened. Furthermore, since all the documents promote the viceroyalty of Ormond as the guarantor of the liberties of the immigrants, it is unlikely that manuscripts recruiting Huguenots went into circulation just before his removal in 1669 , and more probable that they did so after his return as lord lieutenant in 1677. It is also unlikely that they were circulating before April 1679, since Ormond's renewed efforts to attract Huguenots to Ireland were frustrated by their unwillingness to transplant in large numbers. ${ }^{36}$ That situation had changed by the time the manuscript prospectus went into circulation, because it assumes the existence of large numbers of people eager for asylum. This makes it more likely that the manuscript and printed prospectuses were written at about the same time in response to the mass exodus of Huguenots from France in 1681.

However, significant discrepancies between the documents point to tensions between the expectation of the receiving culture and those of prospective refugees. Although Drelincourt mentions the French church in his printed pamphlet, he is less concerned with religious observance, and more with the solidity of the Protestant political nation, which he seeks to impress on those who read his recruiting document or heard it being read:

Au reste, la Religion Protestante y a la Justice, le Pouvoir, et toute l'Authorité en main; soutenue d'une bonne Armée de dix mille hommes, répanduë dans tout le Païs en diverses Garnisons, et composée de Soldats Protestans. ${ }^{37}$

Drelincourt here views Ireland through imperial eyes, representing justice as dependent on an asymmetrical relationship of domination by the Protestant minority of an unmentioned but subjugated Catholic majority. ${ }^{38}$ This discourse, which legitimates an imperialist dynamics of power by equating it with justice, is ostensibly absent from the manuscripts. But its presence is implicit in the

\footnotetext{
35 'in so great a freedom as to the temporal and spiritual'; 'so excellent a government'; 'laws so mild'; 'they must rest assured that they will be favourably received, and will be able to settle easily'(B.N., MS f.fr. 21622, f. 74; MS f.fr. 304, f. 358; [Drelincourt], De l'état present d'Irlande, p. 3).

${ }^{36}$ Sir Cyril Wyche to Ormond, 11 Feb. 1678[/9], 1 Apr. 1679 (H.M.C., Ormonde, n.s., iv, 321; v, 21-2).

37 'Besides, the Protestant religion has the justice system, power, and all authority under control; backed by a fine army of ten thousand men, distributed throughout the country in different garrisons, and made up of Protestant soldiers' ([Drelincourt], De l'état present d'Irlande, p. 5).

${ }^{38}$ M. L. Pratt, Imperial eyes: travel writing and transculturation (London \& New York, 1992), p. 4.
} 
ambiguities that surround the arrangements proposed for the religious observance of the immigrants.

On the one hand, half way through the manuscript documents, permission to worship according to their own Calvinist rites is extended to the Huguenots, provided they pay their own ministers. However, they are advised that if they conform to Anglicanism by attending the French church in the Lady Chapel, then their ministers will receive financial assistance from the government. On the other hand, towards the end, the author of the manuscript seems to change his mind, observing that

Il sembleroit plus convenable de prendre la liturgie Anglicane, comme l'Eglise françoise de Dublin fait, puis qu'outre que c'est la mesme chose au fond et que toute la diferense consiste dans la forme et la maniere qui pourroit bien passer pour indiferente, c'est un moyen de mieux assurer la subsistance de leurs ministres, de se concilier la bien veuillance des princes et d'entretenir plus estroittement l'union qui est tousjours une si belle chose et si digne de vrais Chrestiens. ${ }^{39}$

At this point the author, and those whom he serves, are seeking to secure a reputation for toleration of religious difference, while simultaneously exercising an ideological coercion on the immigrants. Incentives to conform to Anglicanism are offered (remuneration of ministers), which, if refused, would situate the Huguenots on the wrong side of the power on which they depended for survival in a strange land, and would also make them responsible for fracturing the unity proper to true Christians. In other words, despite the offer of freedom of worship, the manuscript recruitment documents were seeking to annex the Huguenots to the Protestant political interest, narrowly defined as the established church. The ambiguities of the manuscript, the silence of the printed pamphlet, and the discrepancies between them on the subject of religion, point to an administration that was undecided about how best to recruit Huguenots to Ireland on a grand scale.

And the scale of the proposals was grand. The manuscript recruitment document offers three, not entirely compatible, options to would-be immigrants. The first of these can only be described as the projection of a geographical fantasy onto the complex reality of seventeenth-century Ireland. Those who read the recruitment documents, or heard them being read, were invited to think of the island as a space eminently open to colonisation, where they could take up residence at will, whether in the towns or the countryside. However, to counterbalance the threat of the unknown, prospective immigrants were also invited to situate themselves imaginatively within an already established Protestant settler-society. The Protestant peoples of Ireland, they were assured, would welcome them with open arms; the landlords on whose lands they chose to settle would offer full protection, as would the lord lieutenant. Finally, the indigenous residents are mentioned, almost as an afterthought, as a presence that would be bounded, rendered harmless, even bypassed, by the colonial frontier that the Huguenots were encouraged to establish:

39 'It would seem more appropriate to accept the Anglican liturgy, as does the French Church of Dublin, since besides the fact that it is the same thing in the end and any difference consists in the form and manner, which could be thought unimportant, it is the way to ensure the upkeep of their ministers, to win the benevolence of the authorities (princes), and to maintain that close union, which is always such a beautiful thing and so worthy of true Christians' (B.N., MS f.fr. 21662, f. 75). 
L'autre chose est qu'il seroit à propos que ceux qui voudront venir se joignent ensemble pour s'establir comme par petites colonies afin qu'ils puissent s'ayder et se maintenir l'un l'autre et se passer plus aisement des originaires du pays. ${ }^{40}$

While the writer remains undecided about what mode of colonisation to promote - virgin territory, settler-society, or Huguenot colonies on land occupied by others - one thing is obvious about the landscape to be colonised. It is remarkably empty, almost depopulated. Neither Protestant landowners nor native peoples provide any obstacle to the proposed colonisation of the island by French Protestants. In other words, this is a poetics of space, a representation drawn from colonial imaginings: it is Ireland as fabricated construct rather than reality. ${ }^{41}$ These were also the poetics of space proposed to Huguenots to entice them to resettle in North America. ${ }^{42}$

Significantly, Drelincourt is more cautious in the printed recruitment document about the opportunities open to immigrants, and seems concerned to limit the colonial imaginings of the immigrants. He observes:

Je say bien que ce Païs passe pour sauvage et barbare; et je l'ay cru tel aussi. Mais, Monsieur, il n'est pas si desert qu'on se le figure, et quoy qu'il ne soit pas aussi peuplé qu'il seroit à souhaiter, il n'y a point de Terres, mêmes les plus incultes, qui ne soient baillées ferme. Tellement qu'il n'y a point ici de Terres Inconnuës, ni de nouvelles Découvertes à faire. Cependant il est d'une étenduë si vaste et le Terroir en est si bon qu'il peut aisément recevoir, et maintenir d[eux] fois plus d'Habitans, qu'il n'y en a. C'est la seule chose qui y manque, tant pour y établir toutes sortes de Manufactures, que pour y cultiver les Terres, qui demeurent en friche, ou faute d'Habitans, ou par l'extréme fainéantise des Naturels. ${ }^{43}$

Here Drelincourt simultaneously subverts one kind of colonialism while also promoting another, possibly because he wanted to encourage the Huguenots to imagine themselves not as pioneers but rather as contributors to the broader imperialist objectives of the local Protestant landlords - as participants in the

40 'The other thing is that it would be appropriate for those who want to come to get together in settlements like little colonies so that they can help and support each other and do without the native population more easily' (ibid.).

4 Edward Said, Orientalism: Western conceptions of the Orient (2nd ed., Harmondsworth, 1995), pp 54-5; idem, Culture and imperialism (London, 1993), pp 6, 93; John McLeod, Beginning postcolonialism (Manchester, 2000), p. 59.

${ }^{42}$ Gilbert Chinard (ed.), Un François en Virginie: voyages d'un François exile pour la religion avec une description de la Virgine et Marilan dans l'Amérique. D'après l'édition originale de 1687 (Paris, 1932), p. 27; Bertrand van Ruymbeke, 'Le refuge huguenot en Caroline du Sud: terre d'exile ou terre promise?' in Bulletin de la Société de l'Histoire du Protestantisme Français, cxli (1995), pp 185-206.

${ }^{43}$ 'I am aware that this country is generally thought of as wild and barbarian; and I thought it was too. But, Monsieur, it is not as deserted as people imagine, and although it is not as populated as one might wish, there are no plots of land, even the most uncultivated, that are not definitively leased out. So much so, that there are no terra incognita here, or any new discoveries to be made. However, it is so vast and extensive, and the land is so good that it could easily welcome and support twice as many inhabitants than it has. That is the only thing wanting, as much for establishing all kinds of manufactures, as for cultivating plots of land that are lying fallow; either for want of inhabitants, or because of the extreme idleness of the natives' ([Drelincourt], De l'état present d'Irlande, $\mathrm{pp} 3-4$ ). 
expansion of commercial agriculture, trade and commerce. ${ }^{44}$ To this end, he presents the landscape not as empty but uncrowded, and bestows positional superiority on the immigrants by encouraging them to think that the land and its indigenous residents require their - that is, the immigrants' - industry. ${ }^{45}$

Similarly, although Drelincourt, as we have just seen, subverts the stereotype that was common at the time, of the Irish as barbarians, ${ }^{46}$ he nonetheless encourages readers to think of the indigenous population as civilisationally inferior:

$D^{\prime}$ ailleurs il ne faut pas s'imaginer qu'il n'y ait que des Irlandois, et qu'on y vive parmi des Sauvages ... quoy qu'il y ait, comme par tout ailleurs, des Gens rustres et des Brutaux; je ne croy pas qu'on y soit moins civilisé qu'ailleurs. Il y a quantité d'Anglois, et d'Ecossois: des Cantons, et des Villes mémes, où ils ne veulent point souffrir d'Irlandois parmi eux. Et ces Irlandois, quoy que nombreux, si on excepte quelques Personnes considérables par leur Qualitê, ou leur Bien; ne sont la plûpart que des misérables, qui vivent dans une lâcheté honteuse, et dans une paresse étrange. ${ }^{47}$

Not barbarians, then, but possibly savages, and certainly lazy natives - the thetoric is undecided. At the risk of labouring the point, let me observe that this is not ethnographic description, but mythic representation shot through with the binary oppositions that legitimate colonial dispossession and imperialist rule: the English and Scottish are civilised, while the Irish are strange and degenerate. ${ }^{48}$ Indirectly Drelincourt seeks to assuage the fears which French Protestants might harbour concerning the Catholic Irish through his presentation of the relationship between newcomer and native as one of separation, exclusion and apartheid, delineating 'us' as against all of 'them'. ${ }^{49} \mathrm{He}$ is also using a symbolic code that serves to include immigrating Huguenots, who, of all peoples at that time, were most likely to situate themselves discursively on the side of the civilised ${ }^{50}$ In other words, Drelincourt is concerned to promote Ireland as a destination that is

${ }^{44}$ I am adopting the distinction between colonialism (the settling of communities from one land in another) and imperialism (the extension of trade and commerce under the protection of political, legal and military controls) mooted by Peter Childs and R. J. P. Williams, An introduction to post-colonial theory (Hemel Hempstead, 1997), p. 227.

${ }^{45}$ For the concept of positional superiority see Said, Orientalism, p. 7; idem, Culture \& imperialism, p. 8.

4h Nicholas Canny, "The ideology of English colonization: from Ireland to America' in William \& Mary Quart., xxx (1973), pp 575-98.

47 'Besides, you must not imagine that there are only Irish here, and that we are living among savages ... although here, like everywhere else, there are rustic and brutish people, I to not believe that we are less civilised here than elsewhere. There are a number of English and Scottish people, cantons and even towns where they will not tolerate the Irish among them. And the Irish, although numerous, saving some persons notable for their quality or possessions, are but mostly paupers, who live in a shameful listlessness, and a strange indolence' ([Drelincourt], De l'etat present d'Irlande, p. 4). For the consideration of peoples as civilisationally inferior see Said, Orientalism, p. 14.

${ }^{45}$ For a consolidated list of Orientalist stereotypes see Said, Orientalism, pp 38-9; idem, Culture \& imperialism, p. 48; McLeod, Beginning postcolonialism, pp 44-6.

${ }^{49}$ Pratt, Imperial eyes, p. 7; Said, Orientalism, p. 7.

50 J. C. Alexander, 'Citizen and enemy as symbolic classification: on the polarizing discourse of civil society' in Michele Lamont and Marcel Fournier (eds), Cultivating difference: symbolic boundaries and the making of inequality (Chicago, 1992), pp 289-308; Myriam Yardeni, 'Le refuge allemand et la France: histoire d'une aliénation' in 
safe and, because it is safe, ripe for the kind of economic exploitation that would confer prosperity on prospective colonisers who were prepared to throw in their lot with the Protestant establishment.

III

The hesitations and ambiguities of these documents point to an intertextuality, even an implicit dialogue, with other contemporaneous recruitment documents and schemes designed to attract the refugees. On the one hand, Drelincourt annexes the Irish scheme to that of England, holding out the prospect of an act of general naturalisation, which he was confident would be passed "par le prémier Parlement d'Irlande, ou d'Angleterre', although this proved to be a false hope. He advertises the efforts made in Dublin to collect money for emergency relief, and he also refers to the measures taken to house refugees in the short term until they could be otherwise provided for, or settled over the long term by providing them with the tools for their trade or suitable assistance. ${ }^{51}$ On the other hand, when Drelincourt alludes to terra incognita, only to deny that those kinds of opportunities exist in Ireland, he is contrasting the Irish scheme to planned immigration schemes to North America. We know that recruitment documents, promoting British North America, were circulating among Huguenots in France, and also in London, which became a kind of clearing-house for refugees keen to leave for more promising destinations. ${ }^{52}$ Significantly, in 1681 Charles de Rochefort, a Huguenot pastor, published a forty-page supplement to his Histoire naturelle et morale des Isles Antilles, promoting Virginia and Maryland as destinations open to those adventurous enough to travel overseas. ${ }^{53}$ That Drelincourt had this propaganda in mind as he wrote is undeniable, since he expresses surprise 'de voir nos François courir les Mers, pour se chercher des Etablissemens parmi les Indiens, et les Sauvages de l'Amérique, quand ils ont si prés d'eux un si bon Païs' ${ }^{54}$ It is clear that Drelincourt, at Ormond's instigation, is competing with contemporaneous immigration schemes and writing his own recruitment document in such a way as to make Ireland more attractive to French Protestant refugees.

This wider context, or Atlantic perspective $e^{55}$ - which has been ignored by those writing about the Irish refuge - makes more sense of the recruitment

eadem, Le refuge Huguenot: assimilation et culture (Paris, 2002), p. 197, makes this point about the refugees' attitude to Germany, to which, as they believed, they brought civilisation.

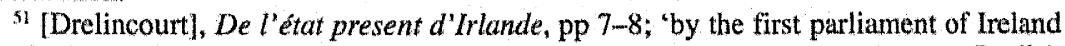
or England' (ibid.). In fact an act of general naturalisation was not passed by the English parliament until 1709, and was soon repealed (Gwynn, Huguenot heritage, pp 152-3).

${ }^{52}$ Van Ruymbeke, 'Le refuge huguenot en Caroline du Sud', pp 194-5.

${ }^{53}$ Chinard (ed.), Un François en Virginie, p. 14.

s4. 'to see our French people rushing overseas looking for settlements for themselves among the Indians and savages of America, when they have such a good country so close to them'([Drelincourt], De l'état present d'Irlande, p. 3).

${ }_{55}$ Bertrand van Ruymbeke, 'Le refuge in an Atlantic perspective: the Huguenot experience in British North America, 1670-1740' (forthcoming); Nicholas Canny, Kingdom and colony: Ireland in the Atlantic world, 1560-1800 (Baltimore, Md., 1988), 
documents promoting Ireland. French Protestants arriving in England in the aftermath of the dragonnades tended to gravitate towards London, which offered prospects of employment and was a centre for relief assistance. Although substantial sums of money were raised to assist the mass of poor refugees who continued to pour into the city, they proved inadequate to meet the demand.$^{56} \mathrm{~A}$ memorial to Henry Compton, bishop of London, probably written during the summer of 1681 , pointed out 'the absolute necessity there is to free the town from the great number of Protestants who arrive daily from France, and to procure them a settlement for gaining their livelihood'. Recruitment agents were clearly at work among the new arrivals, probably promoting North America and the West Indies, since the memorial proposed to create settlements in the English counties, the earliest of which were established at Ipswich and Rye in 1681. The aim of creating new colonies was first and foremost to promote new industries in England, but the writers also observed that this would be "the means to calm the spirits of those poor people, who are much alarmed by the fear of being obliged to cross the sea again'. ${ }^{57}$ My hypothesis is that the manuscript documents were sent out at this juncture, since, as early as August 1681, Ormond was aware that Huguenots in England 'seem to be very desirous to transplant themselves'. However, he was in possession of a memorial that he judged misleading because its author supposed that Ireland "was desolate and more dangerous for Protestants than places in the Continent'. Yet Ormond hoped that the Huguenots 'would prepare for reception on easy terms, for certainly this kingdom is the safest retreat for them in Europe, hardly excepting England' ${ }^{58}$ The manuscript prospectus offered those easy terms, leaving open the possibility of freedom of worship, presenting prospects of resettlement and prosperity, and promoting Ireland as a safe place because it was securely Protestant - even if they did have to cross the proverbially dangerous Irish Sea to get there. ${ }^{59}$

However, a cautionary note was also sounded. The manuscripts made it quite clear that Ireland, unlike England perhaps, was not a charity-destination ready to embrace indigent refugees:

Il est tousjours fort dificile à ceux qui n'ont rien de faire un bon establissement, et quelque bon et abondant que ce soit ce pays on y peut mourir de faim comme ailleurs. Mais il ne sera pas mal aisé à ceux qui ont du bien ou de bonnes vaccations de s'y bien établir et les pauvres y vivront avec les riches aussi bien qu'en tout autre pays, et mieux encore pourveu qu'ils ne veuillent pas joindre à la pauvreté le mauvais mesnage ou la feneantise. ${ }^{.0}$.

${ }^{46}$ Gwynn, Huguenot heritage, pp 44, 71.

${ }^{5}$ Cal. S.P. dom., 1680-81, pp 697-8. The experience of crossing the Atlantic, "that frightful ocean', etched itself deeply into the consciousness of migrants to the Americas, and of those whom they influenced in the early modern period: see J. H. Elliott, 'Colonial identity in the Atlantic world" in Nicholas Canny and Anthony Pagden (eds), Colonial identity in the Atlantic world, 1500-1800 (Princeton, 1987), pp 3-12; Cressy, Coming over, pp 144-77.

${ }^{58}$ Ormond to Abp Boyle, 1 Aug. 1681 (H.M.C., Ormonde, n.s., vi, 116).

${ }^{59}$ Gerard Boate, Histoire naturelle d'Irlande (Paris, 1666), pp 90-91 (a translation of the English edition of 1652).

(2) 'It is always very difficult for those who have nothing to set themselves up well, and no matter how good and bounteous this country is, people can die of hunger here as elsewhere. But it will not be difficult for those who have some capital or reliable trades to 
Rather, Ireland is being promoted first and foremost as a destination for the rich - for those Huguenots who managed to bring some capital with them, which Ormond pledged himself in this document to invest at interest rates of 10 per cent - and for skilled artisans. The indigent were to be welcomed only if they were sober and hard-working, and they were warned that if they undertook to settle on Ormond's lands, they were not to expect free housing on arrival. However, it is added, he would undertake to provide them with land and housing on reasonable terms. ${ }^{61}$ The incentives offered to the adventurous poor are designed to hold out the possibility of prosperity and security of tenure as a reward for industry and their co-operation in expanding building, trade and commercial agriculture on already existing settlements, whether in towns or on landed estates.

The manuscripts are also implicitly in competitive dialogue with recruitment documents promoting North America, which also targeted rich and/or industrious Huguenots. ${ }^{62}$ This is the reason, in my view, that they are so undecided about the model of settlement they want to promote. They are concerned to capture the attention of Huguenots adventurous enough to sign up for overseas destinations, by promoting Ireland on similar terms, while subtly shifting the attention to the real conditions on offer. They also promote Ireland as a superior destination, because of its proximity, as a place holding out the possibility of adventure and asylum, yet near to hand:

Une telle terre peut estre une bonne retraitte et d'autant meilleure qu'estant si proche d'eux ils peuvent aisement et à peu de frais s'y transporter. ${ }^{63}$

Moreover, since emigrants to the America colonies and the West Indies could take advantage of cheap berths on cargo vessels that had conveyed commodities from the 'New World' to Europe, ${ }^{64}$ the writer gives an undertaking from Ormond to provide transportation to Ireland from any British port, and even guarantees them the protection of a naval convoy should circumstances require it. ${ }^{65}$ To this end, he requests a list of those intending to come, giving not their names, but the number of individuals and families, their qualities, property and trades, so that they could be transported directly to the places that the receiving society deemed most suitable. ${ }^{66}$

It is possible that, in response to this promotional literature and the activities of Ormond's agents, Huguenots began arriving in Ireland. Numbers rose sharply in the 1680 s, reaching an estimated total of 600 immigrants by 1685 . Perhaps they

set themselves up well, and the poor can live here with the rich as well as in any other country, and even better, as long as they do not add bad husbandry or idleness to poverty" (B.N., MS f.fr. 21622, f. 74).

${ }^{6}$ Ibid.

${ }^{62}$ Van Ruymbeke, 'Le refuge huguenot en Caroline du Sud', p. 197.

63. A country like this could be a fine sanctuary, all the better because being so near to them they can easily be transported here at little cost' (B.N., MS f.fr. 21622, f. 74). On the high cost of transplantation to North America see Cressy, Coming over, pp 107-29.

${ }^{64}$ Canny, 'In search of a better home?', p. 278.

${ }^{65}$ Without a protective convoy, emigrant ships were vulnerable to privateers (Cressy, Coming over, p. 161).

${ }^{66}$ B.N., MS f.fr. 21622, f. 75 . Government controls on emigration required such lists to be established by officials before emigrants could leave England (Cressy, Coming over, pp 130-43). 
came with unrealistic expectations, given the undecided nature of the rhetoric used to make the island enticing to refugees based in London. Or perhaps they held back because - to borrow a phrase from the aldermen of Bristol - they were 'of the meanest rank and in need of present relief' ${ }^{\prime 7}$ and feared they might indeed die of hunger in Ireland. And so Drelincourt wrote a second recruitment document, the printed one, in the form of a letter to a friend in England, mentioning only the French church at St Patrick's, and reassuring potential settlers as to the short-term and long-term provisions being put in place.

Significantly, both manuscript and printed prospectuses use a catch-phrase to describe Ireland that is widely present in recruitment propaganda designed for French Protestants at the time. Having extolled the fertility of the land, the temperate climate, and the advantages the country offered for trade and commerce, all writers observe that 'c'est un pays découlant de lait et de miel' ${ }^{68}$ This is the phrase used in Scripture to refer to Canaan, symbolising it as rich and productive - indeed, as Israel's 'promised land'. It points to the presence in these documents of a rhetorical strategy, which is routinely at work in Orientalist discourse. In this case, Ireland is alternating 'in the mind's geography between being an Old World to which one returned, as to Eden or Paradise, there to set up a new version of the old, and being a wholly new place to which one came as Columbus came to America, in order to set up a New World' ${ }^{69}$ The effect of such a strategy is to reassure, to make the unfamiliar and even threatening destination that was Ireland seem more rather than less familiar, a place that, while unknown to the refugees, promised to be a version of what was previously known. Indeed, it made Ireland a providential destination, in the strongest meaning of that term, that is, a land offered to the Huguenots by God, which offered 'une Retraite aisée, et un Asyle favorable contre les atteintes de 1'oppression'. ${ }^{70}$ However, Israel was hostile to Canaan, and loathed its religion and way of life, so the use of this trope to describe Ireland also suggests a self-identification with the Israel whose literature urged the eradication of the Canaanite people together with their religion (Deuteronomy 20: 16-18). This is an imaginative geography that enabled the refugees to set up boundaries in their minds that transformed the indigenous population into an alien (although not quite barbarous) other, whose culture and mentality was designated as different from their own. It appealed at one and the same time to the spirit of adventure that made Huguenots sign up for overseas destinations and to their need for security. It allowed them to think of a land that was imaginatively distant, yet geographically near, a land that they did not possess, a land that was lived on by others, as potentially their own. ${ }^{71}$

\footnotetext{
${ }^{67}$ Mayor Thomas Earle and four aldermen to Secretary Jenkins, 10 Dec. 1681 (Cal. S.P. dom. 1680-81, p. 609).

6* 'it is a land flowing with milk and honey' (B.N., MS f.fr. 21622, f. 74; MS f.fr. 304, f. 358; [Drelincourt], De l'état present d'Irlande, p. 4).

${ }^{64}$ Said, Orientalism, p. 58.

* an easy sanctuary, and a favourably disposed asylum against the attacks of oppression' ([Drelincourt], De l'état present d'Irlande, p. 5).

${ }^{71}$ Said, Orientalism, p. 54; idem, Culture \& imperialism, p. 6.
} 
A number of conclusions follow from this analysis of recruitment propaganda aimed at attracting French Protestant settlers to Ireland in the 1680s. It is obvious that Robin Gwynn was mistaken when he claimed that Ormond failed to seize 'the outstanding opportunity to resume encouragement of Huguenot immigration [that] occurred as the tempo of persecution increased in France, from 1679 onwards'. ${ }^{2}$ As these documents reveal, Ormond not only acted promptly to promote Ireland as a destination and to provide incentives; he was also centrally engaged in devising a plan, which took shape progressively in response to the movement of Huguenots out of France. That he and other Irish landlords were actively involved in attracting French Protestant tenants to Ireland confirms the claim that migration to early modern Ireland was not necessarily an individual decision. ${ }^{73}$ Although some Huguenots arrived in Dublin in 1681, probably because kinship or trade networks beckoned, the sharp rise in numbers thereafter suggests that the majority may have come because they were recruited. The epistolary form adopted by Pierre Drelincourt in his published pamphlet is telling in this respect: he was using a rhetorical form that encouraged readers to imagine that they already had a connectedness to Ireland. As Nicholas Canny has argued, 'would-be emigrants were always eager for information about the places they hoped to settle', and 'they expected those of their community who had preceded them to provide them with some knowledge of their experience'. ${ }^{74}$ While the 1662 act provided a legal framework that encouraged inward migration, landlords actually shaped and influenced the patterns of settlement both by the terms they advertised in their promotional literature and by the conditions they offered to settlers once they had arrived. According to Raymond Gillespie, this happened on two occasions in seventeenth-century Ireland, namely the plantation in Ulster at the beginning of the century, and in response to the 1662 act. $^{75}$ However, the existence of recruitment documents aimed specifically at Huguenots in the 1680 s points to a third planned immigration scheme, which extended the provisions of the 1662 act and was later, in the $1690 \mathrm{~s}$, to go beyond them. This drive to recruitment could have acted as a strong 'pull' factor for refugees from France, but it met with only limited success.

The disappointing response to the promotion of Ireland as, to quote Pierre Drelincourt, a 'Sanctuary' for 'those that are opress'd and persecuted, only for their obedience to God, his Gospel, and their Conscience ${ }^{776}$ may be attributed to social, economic and religious factors. As we have seen, state and landlords both hoped to attract not only the skilled labour but also the wealth they presumed the

\footnotetext{
${ }^{72}$ Gwynn, 'Government policy', p. 215. This claim is repeated by Hylton, Ireland's Huguenots \& their refuge, pp 34-5.

${ }^{73}$ Gillespie, 'Planned migration', p. 41.

${ }^{74}$ Canny, 'In search of a better home?', p. 278.

75 Gillespie, 'Planned migration', p. 42 ,

${ }^{76}$ Pierre Drelincourt, A speech made to his grace the duke of Ormond, lord lieutenant of Ireland, and to the lords of his Majesties most honorable privy council, to return the humble thanks of the French Protestants lately arriv'd in this kingdom, and graciously reliev'd by them (Dublin, 1682), pp 3, 5 .
} 
Huguenots would be able to bring with them. Drelincourt's speech of thanks made on their behalf in 1682 reveals that the second of these hopes was an illusion:

They come with their Lives you have so generously preserv'd; but I can't say, with their Fortunes, alas! most of them have none other, but a part of your own. But they come with honest Hearts, full of Gratitude towards their Benefactors; full of Loyalty towards the King, the Defender of their Faith, and of their Persons; of Obedience and Conformity to the best Christian setled Church: full of Love and Meekness, of a peaceable temper and disposition towards their new fellow Citizens; and full of Pray'rs and devout wishes for the prosperity and welfare of this Church and State. ${ }^{77}$

The fact that Drelincourt's speech was published in English at Ormond's instigation suggests that, while the gratitude expressed was sincere, the publication of it was a kind of propaganda directed towards the receiving society. At the time of writing only Ormond himself and Dublin Corporation had provided support for the refugees. These measures, and no doubt the presence of foreign workers in the city, had already created discontent. During the May Day revels in 1682 there was an attempted riot by about three hundred Dublin apprentices who were planning to "destroy the French Protestants who had taken shelter here, ${ }^{78}$ And the landlords in the country at large seem to have been holding back, since, significantly, Drelincourt spoke only of his hope that the generosity of Ormond and the privy council would 'shortly' influence 'the whole Kingdom into an Obedience to that true Christian, and royal Law of Beneficence and Mercy" ${ }^{79}$ It is likely that Drelincourt's speech was printed after the May Day revels; the attitudes of loyalty to state and church he attributes to the refugees point to a desire to counteract the xenophobia of the receiving society. There was a backlash in England too at this time, where the refugees were perceived as hostile to the established church and a threat to the livelihood of "the common people'. Sir Roger L'Estrange wrote in 1681 that they believed 'that they [the refugees] come to take the Bread out of their Mouths, by over-stocking those populous Manufactures, which seem already to be overcharged, and by surfeiting the land with people'. ${ }^{80}$ The Dublin apprentices were no doubt motivated by similar fears, which made them fixate on those aspects of the foreigners they found most threatening: their Calvinist religion and their poverty.

It is possible that the French, who had but recently arrived in Ireland, and were reeling from the trauma of forced conversion and flight, were as meek in their gratitude and conformity as Drelincourt wanted those who heard or read his speech to believe. However, although their loyalty to the king was unquestionable, there is some evidence that they were less than enthusiastic about the arrangements made for religious worship. On 27 June 1683 Archbishop Boyle wrote to Ormond, alerting him to 'the disorder in the French Protestant congregation occasioned by the impertinence of the new-come minister', who had joined 'an English conventicle' (probably a Presbyterian congregation) and

${ }^{71}$ Ibid., p. 7 .

${ }^{78}$ Arran to Jenkins, 2 May 1682 (Cal. S.P. dom., 1680-81, p. 320),

${ }^{79}$ Drelincourt, Speech, p. 4.

[Sir Roger L'Estrange], Apology for the Protestants of France (London, 1683), p. [i]; this work first appeared in 1681 . 
had drawn at least two others with him. ${ }^{81}$ The authorities acted decisively and imprisoned the offenders, whose 'obedience and conformity to the best Christian setled Church' left a lot to be desired; as Ormond observed, 'Though they excuse themselves upon ignorance, yet I do not find that they promise to offend no more as they did. ${ }^{82}$ Undeterred by this severity, a second Huguenot pastor took to intercepting the French as they emerged from services in the Lady Chapel, in the hope of setting up a congregation in Dublin, and celebrated the Lord's Supper with them according to the French Reformed rite. He was forced to leave the country. ${ }^{83}$ It would seem that in the aftermath of the Rye House Plot, Ormond and his deputies in Ireland thought better of the pragmatic accommodation of conformity and nonconformity proposed in the manuscript recruitment documents. In other words, Ireland was not 'a free country' where 'for the first time the Huguenots discovered freedom'. Nor was it 'a tolerant community', as some have argued. ${ }^{84}$ On the contrary, it was precisely because religious freedom was wanting that Huguenots were reluctant to settle in Ireland, as one eighteenthcentury commentator observed: 'Il n'est pas surprenant ... que les Réfugiez, qui avoient la liberté du choix dans tous les autres pays Protestants, ne soient pas venus habiter celui ci, pendant qu'il y avoit de la contrainte. ${ }^{85}$ Although the legal framework was in place to encourage inward migration, political, religious, economic and social ambivalence meant that planning for the colonisation of Ireland by immigrating French Protestants never really took off in the $1680 \mathrm{~s}$.

What the authorities wanted was an industrious, skilled labour force which could be induced to conform to Anglicanism and settle in the towns and on the landed estates of those landlords who were eager to recruit tenants but not to dispense charity. The planned immigration of Huguenots into Ireland was, then, only one part of a much larger social and economic experiment to colonise Ireland by plantation, land confiscation and dispossession, whereby unwanted Irish Catholics could be replaced with more desirable Protestant immigrants. That the writers of the recruitment documents studied here were not troubled by such an experiment is obvious, given the discursive strategies they used, and which they shared with sixteenth- and seventeenth-century colonial discourses internationally. These discourses promoted 'migration that was articulated

${ }^{11}$ Ormond to Abp Boyle, 7 July 1683 (H.M.C., Ormonde, n.s., vii, 65-6); Whelan, 'Liberté de culte', p. 73; Hylton, Ireland's Huguenots \& their refuge, p. 40.

${ }^{82}$ Ormond to Boyle, 7 July 1683 (H.M.C., Ormonde, n.s., vii, 65-6); Arran to Ormond, 24 July 1683 (ibid., p. 81); Ormond to Arran, 11 Aug. 1683 (ibid., p. 104).

${ }^{83}$ R. P. Hylton, 'The less-favoured refuge: Ireland's nonconformist Huguenots at the turn of the eighteenth century' in Kevin Herlihy (ed.), The religion of Irish dissent, 1650-1800 (Dublin, 1996), p. 87; Whelan, 'Liberté de culte', p. 73.

${ }^{84}$ C. E. J. Caldicott, 'The legacy of the Huguenots' in Huguenot Soc. Proc., xxvi (1995), p. 356; J. C. Beckett, Protestant dissent in Ireland, 1687-1780 (London, 1948), p. 16.

${ }^{85}$ Apologie des François reffugiez establis en Irlande, escritte à l'occasion d'un article qui les regarde dans la derniere Representation que le clergé de ce royaume a faitte à sa majeste (Dublin, 1712), p. 6. This pamphlet was also published in English as An apology of the French refugees established in Ireland ... (Dublin, 1712), where the reference is on p. 7: 'So it is not surprising that the French refugees, who had in all other Protestant Countries the Liberty of Worship after their own Way, did not come to live in this, while there was no such permission.' The French version names the lack of permission more bluntly as coercion (contrainte). 
mainly through monopoly of landownership, to implant "civilisation" in place of "savagery". loyal settlers in place of disloyal natives, farmers instead of herders, Protestants instead of "papists" ${ }^{86}$ Significantly, Drelincourt refers readers who are curious about Ireland to the French translation of Gerard Boate's Irelands naturall history (1652), which celebrated the achievements of Protestant settlers and believed the dispossession of Catholics to be justified because of the atrocities committed in $1641 .^{87}$ It is futile to deny that the Huguenots promoted Ireland in a similar - nay, identical - manner, or to seek to mitigate the fact that they viewed it through imperial eyes, as some commentators have done, by introducing spurious distinctions "between plantation and what may be described as enlightened incentives for resettlement'. 88 The incentives offered, as we have seen. were designed to motivate Huguenots to 'transplant into Ireland', to quote Sir Cyril Wyche, 'both at once to strengthen the Protestants' hands, and in some measure to supply the only things that country wants, multitude of people and manual arts" "However, while the majority of Huguenots shared the receiving society's suspicion of "popery' (that is, of a political system as distinct from individual Catholics) and their desire for prosperity, they did not, indeed could not, identify with Anglicanism. ${ }^{90}$

What the Huguenots wanted was to recreate a French Reformed enclave in Ireland, which could be segregated from the majority Catholic population and remain distinct from the receiving Protestant society. ${ }^{91}$ Theirs was an essentially conservative migration. They were refugees, after all, who travelled to foreign lands not out of curiosity or in search of moral or intellectual improvement, ${ }^{92}$ but out of a pressing need for asylum. In fact they left home in order to stay the same, to preserve their way of life and the religious identity that made their lives meaningful to them. They wanted to live abroad as if they were living at home, because they wanted to be poised and ready to return undiminished to the France they thought they had left temporarily. So they did not question the colonial and imperialist models of settlement proposed to them, because those models suited them and spoke to their own fear of 'popery' and of living once again in the midst of a Catholic majority. ${ }^{93}$ Indeed, in the 1690 s, when French Protestants promoted

\footnotetext{
${ }^{\text {Bh }}$ Duffy, 'Migration management', p. 6 .

${ }^{\text {k7 }}$ For the detail of this argument see Whelan, 'Representing Ireland through imperial eyes".

${ }^{4}$ Caldicott et al. (eds), Huguenots \& Ireland, p, 424; C. E. J. Caldicott, 'On short-term and long-term memory' in Huguenot Soc. Proc., xxvii (1999), p. 280.

"Sir Cyril Wyche to Ormond, 11 Feb. 1678[/9] (H.M.C., Ormonde, n.s., iv, 321).

* Ruth Whelan, 'Sanctified by the Word: the Huguenots and Anglican liturgy' in Kevin Herlihy (ed.), Propagating the word of Irish dissent, 1650-1800 (Dublin, 1998), pp 74-94.

91 This was the model they adopted in Germany: see Myriam Yardeni, 'Refuge et encadrement religieux de 1685 à $1715^{\prime}$ in eadem, Le refuge huguenot, p. 60 .

${ }^{92}$ Normand Doiron, 'L'art de voyager. Pour une définition du récit de voyage à l'époque classique' in Poérique, Ixxiii (1988), pp 83-108.

${ }^{93}$ For the detail of this argument see Ruth Whelan, Persecution and toleration: the changing identities of Ireland's Huguenot refugees' in Huguenot Soc. Proc., xxvii (1998), pp 20-35; eadem, 'Remembering with integrity', ibid, (1999), pp 281-3; eadem, 'Writing the self: Huguenot autobiography and the process of assimilation' in Randolph Vigne and Charles Littleton (eds), From strangers to citizens: the integration of immigrant
} 
another, and more elaborate, planned immigration scheme, they again presented Ireland as the 'promised land', whose indigenous population posed no obstacle to their ambition of creating a self-sufficient enclave based on a network of French Protestant towns and colonies. ${ }^{94}$ This scheme also failed to attain the dimensions they had imagined, as had Ormond's. In the final analysis, the immigrants' aspirations were incompatible with those of the Anglican political nation, which was a receiving society eager for their labour, skills and wealth, but suspicious of their French culture and Calvinist religion. In reality, Ireland fell far short of the land that was promised, but this less idealistic interpretation of the Huguenot refuge is a story for another day. ${ }^{95}$

RUTH WHELAN Department of French, National University of Ireland, Maynooth

communities in Britain, Ireland and colonial America, 1550-1750 (Brighton, 2001), pp 463-77; eadem, 'Repressive toleration: the Huguenots in early eighteenth-century Dublin' in eadem and Carol Baxter (ed.), Toleration and religious identity: the Edict of Nantes and its implications in France, Britain and Ireland (Dublin, 2003), pp 179-95; eadem, "Marsh's Library and the French Calvinist tradition: the manuscript diary of Elie Bouhéreau (1643-1719)' in Muriel McCarthy and Ann Simmons (eds), The making of Marsh's Library: learning, politics and religion in Ireland, 1650-1750 (Dublin, 2004), pp 209-34.

${ }^{94}$ Michelle Magdelaine, 'L'Irlande huguenote: utopie ou rélité?' in eadem, MariaCristina Pitassi, Ruth Whelan and Antony McKenna (eds), De l'humanisme aux Lumieres, Bayle et le protestantisme (Paris \& Oxford, 1996), pp 273-87; eadem, 'Conditions et préparation de l'intégration: le voyage de Charles Sailly en Irlande (1693) et le projet d'édit d'accueil' in Vigne \& Littleton (eds), From strangers to citizens, pp 435-41.

${ }^{95} \mathrm{I}$ am grateful to Roger and Line Zuber for their hospitality in Paris, which made it possible to complete some of my research; Bernadette Gardiner, librarian at the National University of Ireland, Maynooth, for her persistence in securing on inter-library loan some of the books I draw on here; and John Hughes, President of the National University of Ireland, Maynooth, who granted me a research professorship (2004-5), which freed me from the ordinary obligations of academic life and bestowed the time to write this atticle. 